\title{
Determine the Factors of Female Early Age at First Cohabitation: A Case Study of Bangladesh
}

\author{
Md. Yasin Ali Parh, Sharmin Aktar Sumy, Md. Sazzad Hossain \\ Department of Statistics, Islamic University, Kushtia, Banglades \\ Email: yali@isrt.ac.bd
}

Received 2 July 2015; accepted 8 October 2015; published 13 October 2015

Copyright (C) 2015 by authors and Scientific Research Publishing Inc.

This work is licensed under the Creative Commons Attribution International License (CC BY). http://creativecommons.org/licenses/by/4.0/

(c) (;) Open Access

\begin{abstract}
The main objective of the current study is to examine the existing situation of female early age at first cohabitation in Bangladesh as well as to identify the factors associated behind this issue. An analysis has been performed by using the secondary data of Bangladesh Demographic and Health Survey (BDHS), 2011. Chi-square test for dependency checking has been performed as bivariate analysis. After performing bivariate analysis, binary logistic regression analysis has been performed. To identify the significant variable, stepwise regression method has also been performed. The result of the study has revealed that women education, household economic status, area of residence, religion and geographical location have significant contribution for adolescent cohabitation. From this study it can be concluded that females who has low education and low socioeconomic status are more likely to enter into cohabitation at early adulthood.
\end{abstract}

\section{Keywords}

Female Early Age at First Cohabitation, Bivariate Analysis, Logistic Regression Analysis, Odds Ratio, Step Wise Regression

\section{Introduction}

Bangladesh is one of the developing and densely populated countries in the world. The population hasn't declined since the last several decades. During the first national population census (1974) of Bangladesh the population has been doubled [1]. The high level of fertility is considered to be one of the main factors for large population size. This high increase of population resulted from a combination of high birth rates and high death rates. Among various factors, female early age at cohabitation is directly related to fertility behavior in this country. 
Early age at cohabitation has a major effect on childbearing because women who marry early have, on an average, a longer period of exposure to the risk of becoming pregnant and a greater number of birth [2]. In a country like Bangladesh along with the control of fertility, it is also important to inquire into the age at cohabitation in any examination of the issue to reduce fertility. The present study has tried to seek some of the dominant factors associated with early age at cohabitation of females in Bangladesh. According to (UNICEF's flagship report, 2011) figures [3], 66 percent of Bangladeshi girls are married before the age of 18 and approximately a third of women were married by the age of 15. In the current study on the basis of the data of BDHS (2011) it is found that 78 percent girls of Bangladesh are cohabited before the age of 18 and only 22 percent girls are cohabited at or after age of 18 although according to the rules of the government of Bangladesh the legal age at first marriage for females is 18 years old. The average age at first marriage for female in Bangladesh is 18.7 years old [4]. It is believed that rural tradition encourages early marriage, while urbanization and other forces of modernization lead to late marriage. According to the [5] early age at marriage is higher in rural area than urban area. In the rural area of Bangladesh there are many social pressures to marry of pubescent girls [6]. If the marriage of a pubescent girl is delayed, her parents and sometimes the girl herself are made to feel guilty. Similar scenarios are more common in slum areas. Poor economic status is one of the major factors of early marriage. Where poverty is severe, an unmarried girl may be considered as an economic burden in the family and parents look for early marriage of their daughters. Low education is one of the important factors of early marriage. It is generally happened that low educated females foster early marriage, while higher educated females lead to late marriage. Low income families are unable to continue the study of their daughter and try to marry their daughter as soon as possible [7]. Results show that women who have more educated marriage delay.

\section{The Objectives of the Present Study}

In this study, it has tried to examine the predictors of early age at cohabitation in Bangladesh. There are several factors that effecting on early age at cohabitation. Thus, a greater attempt has to be made to find out the factors that are influencing early age at cohabitation. More specially, the objectives of the present study are:

- To observe the running situation in female age at first cohabitation in Bangladesh;

- To investigate the causes of early age at cohabitation in Bangladesh;

- To provide better suggestions and take necessary steps to solve the problem.

\section{Data Source and Variables}

The current study based on the data of Bangladesh Demographic and Health Survey (BDHS), 2011. The survey was designed to produce representative estimates for most of the indicators for the country as a whole, for the urban and the rural areas separately, and for each of the seven divisions. The 2011 BDHS is a nationally representative of a total of 17,964 selected households, 17,511 were found to be occupied. Interviews were successfully completed in 17,141 households. A total of 18,222 ever married women age 12 - 49 were identified in these households, and 17,842 were interviewed [8].

\subsection{The Response Variable}

Age at first cohabitation is used as the dependent variable, which is recorded in single years. In the present study the dependent variable is made dichotomous by dividing it into two categories: the girls who have cohabitated before reaching age 18 were considered as early cohabited and the girls, who have cohabited after age 18, were considered as late cohabited. Eighteen years was selected as the cut-off point for defining the state of marriage as this was the legal female age at marriage in Bangladesh. For analytical purposes, females who had cohabited early were considered as the "successes" and coded as 1 . On the other hand, late cohabited females were considered as "failures" and were coded as 0.

Therefore binary logistic regression model has used.

$Y_{i}=1$, if the $i^{\text {th }}$ female in sample was cohabited early and $Y_{i}=0$, if the $i^{\text {th }}$ female in sample was not cohabited early.

Consequently, $p\left(y_{i}=1\right)=\pi\left(X_{i}\right)$, probability that $i^{\text {th }}$ woman was cohabited early and $p\left(y_{i}=0\right)=1-\pi\left(X_{i}\right)$, probability that $i^{\text {th }}$ woman was not cohabited early. 


\subsection{Predictor Variables}

Variables, which showed significant effect association with age at first cohabitation in chi-square tests of bivariate analysis, were selected as explanatory variables. Respondents characteristics selected include their region, highest level of educational attainment, religion, area of residence and media (television, radio and reading newspaper). Besides this, partner's educational level and economic status are also considered as explanatory variables.

For analytical purposes, some predictors have been recoded of the original data. Economic status has coded three categories (poor, middle and rich). Respondents and partner's educational attainment have coded four categories (No education, primary, secondary and higher). Media that are combination of three variables (having radio, television and reading newspaper) have merged two categories. If any one of them is present then it codes 1 (Yes) otherwise 0 (No).

\subsection{Limitations of the Current Study}

The main objective of the current study is to find out the possible predictors of early female age at cohabitation in Bangladesh. The study of cohabitation and related issues has not attracted much attention in past in Bangladesh, as a result, this area is neglected in the various data sources. For example, educational level of fathers and mothers has a great significant effect on early marriage. Unfortunately, no such information is available of the current data.

\section{Methodology}

In the present study both bivariate and multivariate techniques have been applied. Frequency tables, Cross tabulation and Chi-Square tests have been used in the study to examine the determinant of early female age at cohabitation. Logistic regression models are fitted to show the effect of the explanatory variables on early marriage. In the study of [9], it also used linear logistic regression analysis. In this study besides logistic regression analysis stepwise logistic regression analysis is also performed.

\subsection{Logistic Regression Model}

Let,

$Y_{i}=1$, if $i^{\text {th }}$ individual is success and

$Y_{i}=0$, if $i^{\text {th }}$ individual is a failure, for $i=1,2, \cdots, n$.

In the linear logistic regression model the dependency of probability of success on independent variables is assumed to be

$$
\Pi\left(x_{i}\right)=p\left(y_{i}=1 \backslash x\right)=\frac{\exp \left(\beta_{0}+\beta_{1} x_{i 1}+\beta_{2} x_{i 2}+\cdots+\beta_{p} x_{i p}\right)}{1+\exp \left(\beta_{0}+\beta_{1} x_{i 1}+\beta_{2} x_{i 2}+\cdots+\beta_{p} x_{i p}\right)}
$$

and the probability of failure is

$$
1-\pi\left(x_{i}\right)=p\left(y_{i}=0 \backslash x\right)=1-\frac{\exp \left(\beta_{0}+\beta_{1} x_{i 1}+\beta_{2} x_{i 2}+\cdots+\beta_{p} x_{i p}\right)}{1+\exp \left(\beta_{0}+\beta_{1} x_{i 1}+\beta_{2} x_{i 2}+\cdots+\beta_{p} x_{i p}\right)}
$$

The logit transformation of the logistic regression model is. The transformation is defined in terms of $\pi\left(x_{i}\right)$ is as follows:

$$
\lambda_{i}=g\left(x_{i}\right)=\operatorname{logit} \pi\left(x_{i}\right)=\frac{\pi\left(x_{i}\right)}{1-\pi\left(x_{i}\right)}=\beta_{0}+\beta_{1} x_{i 1}+\beta_{2} x_{i 2}+\cdots+\beta_{i} x_{i p}
$$
[10].

The logit $g\left(x_{i}\right)$ is linear in its parameter, continuous and range from $-\infty$ to $+\infty$, depending on the range of $X$

\subsection{Stepwise Regression Method}

Stepwise regression method is also applied to select the significant variables: 
1) Forward stepwise method;

2) Backward stepwise method.

\subsubsection{Forward Selection Method}

The procedure begins with the assumption that there are no regressors in the model other than intercept. At first fit a regression equation by taking a single variable. If it is significant, the model take it; otherwise drop the variable and again fit the regression equation with another single variable in the same manner. The procedures terminates when the last candidate regressor is added to the model.

\subsubsection{Backward Elimination Method}

The general process of this method is fitting a regression equation including all the candidate variables of interest and then removes them one by one. Then drop a single variable by using F statistics and again fit a model. By repeating this process again and again at last the model contains a number of independent variables [11].

\section{Statistical Analysis}

This section provides frequencies of female early age at cohabitation, percentages of early marriage among various categories of the predictors, bivariate analysis result, logistic regression output and stepwise regression results. Table 1 reports the frequency of marital age.

From the frequency table it is found that 77.7 percent girls of Bangladesh are cohabited before the age of 18 and only 22.3 percent girls are cohabited at or after age 18 . The results of the bivariate analysis for the dependent variable age at first cohabitation by their explanatory variables among different categories are reported in Table 2.

From the bivariate analysis it is found that all of the predictor variables come out significant. So these variables can be used for fitting the logistic regression model. Among the division it is observed that early cohabitation has highest proportion in Rangpur division, i.e. among 2469 individual's 85.4 percent of them cohabited before age 18. The next higher early cohabitated proportion is found in Khulna division and the successive decreasing order of proportions of cohabitation before age 18 is Rajshahi, Barisal, Dhaka, Chittagong and Sylhet respectively. This regional differentiation may be occurred due to industrialization, urbanization and education. From the results it is revealed that respondent's education has a strong significant impact on age at first cohabitation. The respondents who have no formal education cohabited early. The result shows that higher educated respondents have tendency to cohabit later than that of primary and secondary educated respondents. From the data it is found that among 1465 higher educated female 70.6 percent of them cohabited after age 18 whereas among 4639 illiterate respondent's 87.3 percent of them cohabited before age 18. It is also observed that the respondents who live in rural area have tendency to cohabit early than the respondents who live in urban area.

Though husband's educational attainment is not as strong as women's educational attainment but has significant association on respondent's age at first cohabitation. It is observed that the respondent's whose husbands are illiterate more cohabited before age 18 than the respondents whose husbands have primary, secondary or higher level of educational attainment. Because educated husbands are likely to cohabit educated females and most of the educated female are aware about their cohabitation age. Access of media has also a significant impact on age at first cohabitation. The proportion of later married is higher among the individual's who have access media than the individual's who have no access of media. From the data it is also found that the respondents who come from rich family cohabit later age as compare to other family status. The rich family's respondent get all the benefit from society like as education, access to mass media and other facilities which directly related to age at first cohabitation. Table 3 reported the results of logistic regression model to the data to examine the impact of those explanatory variables that are showing significant in chi-square test.

Table 1. Frequency table of age at first marriage.

\begin{tabular}{ccc}
\hline Category & Frequency & Percent \\
\hline Late married (less or equal 18) & 3983 & 22.3 \\
Early married (below 18) & 13,859 & 77.7 \\
Total & 17,842 & 100.0 \\
\hline
\end{tabular}


Table 2. Bivariate analysis result.

\begin{tabular}{|c|c|c|c|c|}
\hline \multirow[b]{2}{*}{ Categories of the variables } & \multicolumn{2}{|c|}{ Age at first cohabitation } & \multirow[b]{2}{*}{$\begin{array}{l}\text { Chi-Square Test } \\
\text { value }\end{array}$} & \multirow[b]{2}{*}{ Significance Leve } \\
\hline & $\begin{array}{l}\text { Late married } \\
\text { (\% of total) }\end{array}$ & $\begin{array}{l}\text { Early married } \\
\text { (\% of total) }\end{array}$ & & \\
\hline \multicolumn{5}{|l|}{ Region } \\
\hline Barisal & 19.0 & 81.0 & \multirow{7}{*}{482.949} & \multirow{7}{*}{0.000} \\
\hline Chittagong & 27.2 & 72.8 & & \\
\hline Dhaka & 23.2 & 76.8 & & \\
\hline Khulna & 17.7 & 82.3 & & \\
\hline Rajshahi & 18.3 & 81.7 & & \\
\hline Rangpur & 14.6 & 85.4 & & \\
\hline Sylhet & 37.7 & 62.3 & & \\
\hline \multicolumn{5}{|l|}{ Respondent's education } \\
\hline No education & 12.7 & 87.3 & \multirow{4}{*}{2426.292} & \multirow{4}{*}{0.000} \\
\hline Primary & 14.5 & 85.5 & & \\
\hline Secondary & 24.8 & 75.2 & & \\
\hline Higher & 70.6 & 29.4 & & \\
\hline \multicolumn{5}{|l|}{ Husband's education } \\
\hline No education & 12.4 & 87.6 & \multirow{4}{*}{1523.671} & \multirow{4}{*}{0.000} \\
\hline Primary & 16.2 & 83.8 & & \\
\hline Secondary & 24.3 & 75.7 & & \\
\hline Higher & 49.4 & 50.6 & & \\
\hline \multicolumn{5}{|l|}{ Economic status } \\
\hline Poor & 14.0 & 86.0 & \multirow[t]{3}{*}{680.717} & \multirow[t]{3}{*}{0.000} \\
\hline Middle & 17.1 & 82.9 & & \\
\hline Rich & 31.3 & 68.7 & & \\
\hline \multicolumn{5}{|l|}{ Residence } \\
\hline Urban & 28.7 & 71.3 & \multirow[t]{2}{*}{221.156} & \multirow[t]{2}{*}{0.000} \\
\hline Rural & 18.9 & 81.1 & & \\
\hline \multicolumn{5}{|l|}{ Religion } \\
\hline Muslim & 20.9 & 79.1 & \multirow[t]{2}{*}{176.830} & \multirow[t]{2}{*}{0.000} \\
\hline Non Muslim & 34.0 & 66.0 & & \\
\hline \multicolumn{5}{|c|}{$\begin{array}{c}\text { Media } \\
\text { (radio, television, reading newspaper) }\end{array}$} \\
\hline No & 16.2 & 83.8 & & \\
\hline Yes & 28.2 & 71.8 & 370.798 & 0.000 \\
\hline
\end{tabular}

The results of Table 3 give the estimates of the logistic regression coefficients corresponding to the explanatory variables and their relative odds ratio for each categories of the variable. In logistic regression the interpretation is done in terms of odds ratio. Odds ratio is the ratio of two odds. Odds ratios are used to compare the relative odds of two groups. In this study the categories of each variable compare with the reference category. From the result it is found that region, respondent's education, Husband educational attainment, residence, religion, and economic status all have significant effect on early marriage. The odds ratio under region indicates that in Barisal division early cohabitation occurs 3.630 times more likely than Sylhet and in Chittagong, Dhaka, Khulna, Rajshahi and Rangpur early cohabitation occur 1.980, 2.616, 4.014, 3.411 and 4.561 times respectively more likely than Sylhet. Respondents who have no education are found to have early cohabitation10.800 times more likely compared with those who have higher education. Similarly primary and secondary educational attained female have 9.801 and 5.906 times more likely to have early cohabitation than femal having higher education. Respondents whose husband's are higher educated are seen to get cohabitated adult female. From the result it is observed that early cohabitation occurs 2.021, 1.794 and 1.428 times more likely whose husband's has no education, has primary education and has secondary education compared with those whose husband's are higher educated respectively. It is found that respondents whose residence in rural area are found to have slightly higher early cohabitation comparing with urban area. It is also observed that early cohabitation is higher in Muslim religion compare to other religion. Early cohabitation among women who come from poor families is 1.219 times higher than whose come from rich families and 1.262 times higher in middle class families compare to rich families. Table 4 reports the forward and backward stepwise regression result. 
Table 3. Fitted results of logistic regression model.

\begin{tabular}{|c|c|c|c|}
\hline Categories of the variables & Estimated value & Sig. level & Odds ratio \\
\hline $\begin{array}{c}\text { Region } \\
\text { Barisal } \\
\text { Chittagong } \\
\text { Dhaka } \\
\text { Khulna } \\
\text { Rajshahi } \\
\text { Rangpur } \\
\text { Sylhets (reference) }\end{array}$ & $\begin{array}{l}1.289 \\
0.683 \\
0.962 \\
1.390 \\
1.227 \\
1.518\end{array}$ & $\begin{array}{l}0.000 \\
0.000 \\
0.000 \\
0.000 \\
0.000 \\
0.000 \\
0.000\end{array}$ & $\begin{array}{l}3.630 \\
1.980 \\
2.616 \\
4.014 \\
3.411 \\
4.561\end{array}$ \\
\hline $\begin{array}{c}\text { Respondent's Education } \\
\text { No education } \\
\text { Primary } \\
\text { Secondary } \\
\text { Higher (reference) }\end{array}$ & $\begin{array}{l}2.380 \\
2.282 \\
1.776\end{array}$ & $\begin{array}{l}0.000 \\
0.000 \\
0.000 \\
0.000\end{array}$ & $\begin{array}{c}10.800 \\
9.801 \\
5.906\end{array}$ \\
\hline $\begin{array}{c}\text { Husband's Education } \\
\text { No education } \\
\text { Primary } \\
\text { Secondary } \\
\text { Higher (reference) }\end{array}$ & $\begin{array}{l}0.704 \\
0.584 \\
0.356\end{array}$ & $\begin{array}{l}0.000 \\
0.000 \\
0.000 \\
0.000\end{array}$ & $\begin{array}{l}2.021 \\
1.794 \\
1.428\end{array}$ \\
\hline $\begin{array}{l}\text { Residence } \\
\text { Urban } \\
\text { Rural (referece) }\end{array}$ & 0.091 & 0.047 & 1.095 \\
\hline $\begin{array}{c}\text { Religion } \\
\text { Muslims } \\
\text { Non Muslims (reference) }\end{array}$ & 0.648 & 0.000 & 1.911 \\
\hline $\begin{array}{c}\text { Economic status } \\
\text { Poor } \\
\text { Middle } \\
\text { Rich (reference) }\end{array}$ & $\begin{array}{l}0.198 \\
0.234\end{array}$ & $\begin{array}{l}0.000 \\
0.003 \\
0.000\end{array}$ & $\begin{array}{l}1.219 \\
1.262\end{array}$ \\
\hline $\begin{array}{c}\text { Media (radio, television or reading ne } \\
\text { No } \\
\text { Yes (reference) }\end{array}$ & -0.108 & 0.043 & 0.898 \\
\hline
\end{tabular}

In forward stepwise method it removes the variables residence and media although in backward stepwise method it takes all of the variables and the results are same in the original logistic regression model.

\section{Conclusions}

The study examines the factors of age at first cohabitation in Bangladesh among female adolescents by using the national representative data from the Bangladesh Demographic and Health Survey, 2011. Both bivariate and logistic regression analyses have been performed to identify the important factors of age at first cohabitation. Figure of cohabitation showed that about 77.8 percent respondents were cohabited before age of 18 . The result suggests that early cohabitation among female adolescents is related to multidimensional issues. Logistic regression analysis investigates that the predictors such as region, respondent's educational attainment, husband's educational attainment, residence, economic status and religion are important in explaining the age at first cohabitation of Bangladeshi female adolescents. Among the variables, respondent's educational attainment and husband's educational attainment play vital role in age at first cohabitation of the female adolescents. The results of the current study suggest policy implications about early age at marriage and population growth. To decrease the early age at first marriage and to reduce the growth rate of population, apex importance must be imposed on education of the females. Appropriate steps must be taken to ensure at least higher secondary education level for girls. Form the current study it is also found that husband's education level has significant impact on age at first cohabitation. Hence, it can be advised that male's educational level should also be improved which should be effective to reduce adolescent cohabitation. It is hope for us that the Government of Bangladesh has already taken some initiatives to increase the number of school going children. Both the Government and non-Government organizations should come forward to create job opportunities for females. The literate and wise people 
Table 4. Forward and backward stepwise logistic regression model.

\begin{tabular}{|c|c|c|c|c|c|c|}
\hline \multirow{2}{*}{ Variables and their categories } & \multicolumn{3}{|c|}{ Forward stepwise method } & \multicolumn{3}{|c|}{ Backward stepwise method } \\
\hline & $\begin{array}{l}\text { Estimated } \\
\text { value }\end{array}$ & Sig. & Odds ratio & $\begin{array}{l}\text { Estimated } \\
\text { value }\end{array}$ & Sig. & Odds ratio \\
\hline $\begin{array}{c}\text { Region } \\
\text { Barisal } \\
\text { Chittagong } \\
\text { Dhaka } \\
\text { Khulna } \\
\text { Rajshahi } \\
\text { Rangpur } \\
\text { Sylhet (reference) }\end{array}$ & $\begin{array}{l}1.283 \\
0.680 \\
0.952 \\
1.388 \\
1.229 \\
1.516\end{array}$ & $\begin{array}{l}0.000 \\
0.000 \\
0.000 \\
0.000 \\
0.000 \\
0.000 \\
0.000\end{array}$ & $\begin{array}{l}3.608 \\
1.974 \\
2.590 \\
4.007 \\
3.417 \\
4.554\end{array}$ & $\begin{array}{l}1.289 \\
0.683 \\
0.962 \\
1.390 \\
1.227 \\
1.518\end{array}$ & $\begin{array}{l}0.000 \\
0.000 \\
0.000 \\
0.000 \\
0.000 \\
0.000 \\
0.000\end{array}$ & $\begin{array}{l}3.630 \\
1.980 \\
2.616 \\
4.014 \\
3.411 \\
4.561\end{array}$ \\
\hline Respondent's Education & & 0.000 & & & 0.000 & \\
\hline $\begin{array}{c}\text { No education } \\
\text { Primary } \\
\text { Secondary } \\
\text { Higher (reference) }\end{array}$ & $\begin{array}{l}2.365 \\
2.271 \\
1.775\end{array}$ & $\begin{array}{l}0.000 \\
0.000 \\
0.000\end{array}$ & $\begin{array}{c}10.645 \\
9.685 \\
5.901\end{array}$ & $\begin{array}{l}2.380 \\
2.282 \\
1.776\end{array}$ & $\begin{array}{l}0.000 \\
0.000 \\
0.000\end{array}$ & $\begin{array}{l}10.800 \\
9.801 \\
5.906\end{array}$ \\
\hline $\begin{array}{c}\text { Husband's Education } \\
\text { No education } \\
\text { Primary } \\
\text { Secondary } \\
\text { Higher (reference) }\end{array}$ & $\begin{array}{l}0.699 \\
0.584 \\
0.358\end{array}$ & $\begin{array}{l}0.000 \\
0.000 \\
0.000 \\
0.000\end{array}$ & $\begin{array}{l}2.011 \\
1.793 \\
1.430\end{array}$ & $\begin{array}{l}0.704 \\
0.584 \\
0.356\end{array}$ & $\begin{array}{l}0.000 \\
0.000 \\
0.000 \\
0.000\end{array}$ & $\begin{array}{l}2.021 \\
1.794 \\
1.428\end{array}$ \\
\hline $\begin{array}{c}\text { Religion } \\
\text { Muslims } \\
\text { Non Muslims (reference) }\end{array}$ & 0.641 & 0.000 & 1.898 & 0.648 & 0.000 & 1.911 \\
\hline $\begin{array}{c}\text { Economic status } \\
\text { Poor } \\
\text { Middle } \\
\text { Rich (reference) }\end{array}$ & $\begin{array}{l}0.168 \\
0.233\end{array}$ & $\begin{array}{l}0.000 \\
0.000 \\
0.000\end{array}$ & $\begin{array}{l}1.183 \\
1.263\end{array}$ & $\begin{array}{l}0.198 \\
0.234\end{array}$ & $\begin{array}{l}0.000 \\
0.003 \\
0.004\end{array}$ & $\begin{array}{l}1.219 \\
1.263\end{array}$ \\
\hline $\begin{array}{c}\text { Residence } \\
\text { Rural } \\
\text { Urban (reference) }\end{array}$ & & & & 0.091 & 0.047 & 1.095 \\
\hline $\begin{array}{c}\text { Media } \\
\text { (radio, television or reading } \\
\text { newspaper) } \\
\text { No } \\
\text { Yes (reference) }\end{array}$ & & & & -0.108 & 00.043 & 0.898 \\
\hline
\end{tabular}

in the society should play important role in removing early age at marriage. Finally public awareness is necessary to free the society from the curse of early age at cohabitation.

\section{References}

[1] Population and Housing Census (2011) Socio-Economic and Demographic Report National Series, Volume 4. Bangladesh Bureau of Statistics (BBS), Statistics and Informatics Division (SID), Ministry of Planning.

[2] Nahar, M.Z., Zahangir, M.S. and Islam, S.M.S. (2013) Age at First Marriage and Its Relation to Fertility in Bangladesh. Chinese Journal of Population Resources and Environment, 11, 227-235. http://dx.doi.org/10.1080/10042857.2013.835539

[3] UNICEF (2011) State of the World's Children 2011 to Adolescents. UNICEF’s Flagship Report 2011.

[4] Bangladesh Bureau of Statistics (BBS) (2009) Statistical Pocket Book of Bangladesh. Ministry of Planning, Government of the People's Republic of Bangladesh, Statistics Division, Dhaka.

[5] Rahman, M., Islam, M. and Hossain, M. (2008) Female Age at Marriage of Rural-Urban Differentials in Bangladesh. The Internet Journal of Biological Anthropology, 3.

[6] Aziz, K.M. and Maloney, C. (1985) Life Stages, Gender and Fertility in Bangladesh. International Centre for Diarrhoeal Disease Research, Bangladesh (ICDDR, B), Dhaka.

[7] Gangadharan, L. and Maitra, P. (2000) The Effect of Education on the Timing of Marriage and First Conception in Pa- 
kistan. Working Papers Series with Number 742, Department of Economics, The University of Melbourne, Parkville.

[8] (2011) Bangladesh Demographic and Health Survey (BDHS) 2011. National Institute of Population Research and Training, Dhaka.

[9] Chowdhury, A.H., Hoq, M.Z., Hossain, M.E. and Khan, M.M. (2013) Factors Affecting an Age at First Marriage among Female Adolescents in Bangladesh. Research on Humanities and Social Sciences, 3, 131-139.

[10] Hosmer, D.W. and Lemeshow, S. (2000) Applied Logistic Regression. 2nd Edition, Wiley, New York. http://dx.doi.org/10.1002/0471722146

[11] Montgomery, D.C., Peck, E.A. and Vining, G.G. (2001) Introduction to Linear Regression Analysis. 3rd Edition, Wiley, New York. 